\title{
高濃度浸炭焼入れ歯車の負荷能力に関する研究*
}

\author{
坪倉公治*1, 小出隆夫*2, 小田 哲*3

\section{Study on Load Bearing Capacity of Super-Carburized Gears}

Koji TSUBOKURA*4, Takao KOIDE and Satoshi ODA

\author{
${ }^{* 4}$ Matsue National College of Technology, \\ 14-4 Nishiikuma-cho, Matsue-shi, Shimane, 690-8518 Japan
}

\begin{abstract}
This paper presents a study on the load bearing capacity of super-carburized gears. Test gears and rollers of MAC14 and SCM415 steel were super-carburized or eutectoid-carburized under different carburizing conditions. The bending fatigue and contact fatigue tests were carried out for these test specimens. The effects of case depths on the bending fatigue strength of gears and contact fatigue strength of rollers were determined. The bending fatigue strength of super-carburized gear was found to be almost equal to that of eutectoid-carburized gears. The contact fatigue strength of super-carburized roller becomes larger with an increase of case depth and is larger than that of eutectoid-carburized rollers in the case of larger case depth. The surface failure modes for superand eutectoid-carburized rollers were spalling. The load bearing capacity of super-and eutectoid carburized gears was found to become larger by shotpeening.
\end{abstract}

Key Words: Gear, Roller, Load Bearing Capacity, Super-Carburizing, Eutectoid-Carburizing, Bending Fatigue Strength, Contact Fatigue Strength, Surface Durability, Shot-Peening

\section{1. 緒言}

従来，機械部品の多くは浸炭焼入れによってその而 摩耗性や疲労強度を改善させているが, 近年これらを さらに向上させる方法として，表面近傍の炭素量を従 来の浸炭焼入れ法よりも多くしてマルテンサイトのマ トリックスに粒状の炭化物を生成, 分散させる高濃度 浸炭焼入れ法が開発されている(1). 高濃度浸炭覝入れ を施した材料の疲労強度については，一般的形状の試 験片に対する報告 ${ }^{(2)(3)}$ はあるが，実際の機械部品に対 する研究は極めて少なく ${ }^{(4)}$, 特に高濃度浸炭焼入れに おける硬化層厚さが疲労強度に及ぼす影響についての 研究は見当たらない.

本研究では，高濃度浸炭用鋼材と一般の浸炭用鋼材 を用いて製作した，硬化層厚さの異なる高濃度浸炭お よび共析浸炭焼入れ歯車に対して, 衝撃および曲げ疲 労試験を行って，これらの歯車の衝撃および曲げ疲労 強度について明らかにしている.つぎに，これらの歯

* 原稿受付 2001 年 3 月 26 H。

*1 正員, 松江.工.業高等専門学校 (更690-8518 松江行西生馬町 14-4).

*2 正員, 鳥取大学工学部( 6808552 鳥取俌湖山田南 4 101).

*3 正貟, 福山大学工学部(更729-0292 福山市学園町 1 二蔵).

E-mail : tsubo@me.matsue-ct.ac.jp
車にショットピーニングを施した歯車に対して曲げ疲 労試験を行い, 曲げ疲労強度に及ぼすショットピーニ ングの影響についても明らかにしている.さらに，高 濃度浸炭焼入れ歯車の面圧強度を調べるための基礎研 究として, 硬化層厚さの異なる高濃度浸炭および共析 浸炭焼入れローラに対して二円筒試験を行い, ローラ の面圧強度に及ぼす高濃度浸炭, ショットピーニング の影響などについても検討を加えている.

\section{2. 実験方法および実験装置}

\section{2・1 歯車の街撃および曲げ疲労試験}

$\mathbf{2} \cdot \mathbf{1} \cdot \mathbf{1}$ 試験画車本実験に用いた歯車材料は, 高濃度浸炭用鋼 MAC14(5) と一般の浸炭用鋼 SCM415 で， 化学成分を表 1 に示す. 試験歯車は, これらの材料を ホプ切り加工後, 表 2 に示す条件で熱処理を行ったも ので, モジュール $m=4$, 基準圧力角 $\alpha=20^{\circ}$, 歯数 $z=18$, 歯幅 $b=10 \mathrm{~mm}$ の標準平霜車である.すべての MAC14 歯車と一部の SCM415 歯車（SH2）に対しては高濃度 浸炭を, その他の SCM415 歯車に対しては共析浸炭を

Table1 Chemical composition

\begin{tabular}{c|c|c|c|c|c|c|c|c|c}
\hline Material & $\mathrm{C}$ & $\mathrm{Si}$ & $\mathrm{Mn}$ & $\mathrm{P}$ & $\mathrm{S}$ & $\mathrm{Cu}$ & $\mathrm{Ni}$ & $\mathrm{G}$ & $\mathrm{Mo}$ \\
\hline MAC14 & 0.14 & $\mathbf{0 . 2 7}$ & $\mathbf{0 . 5 0}$ & $\mathbf{0 . 0 1 7}$ & 0.024 & 0.08 & 0.12 & 249 & 038 \\
\hline SCM415 & 0.16 & 0.30 & 0.79 & 0.20 & 0.16 & 0.17 & 0.08 & 1.14 & 0.17 \\
\hline
\end{tabular}


施した．表 2 中の S2P1，M2P1 はショットピーニング 条件 1 （ショット粒径 $0.30 \mathrm{~mm}$ ），S2P2，M2P2 は条件 2 （粒径 $0.60 \mathrm{~mm}$ ）のショットピーニングを施したもの である. ショット粒の硬さは $H_{R} C=60$ である.アーク 八イト值は, 条件 1，2 に対してそれぞれ $0.31 \mathrm{mmA,}$ $0.72 \mathrm{mmA}$ (アルメンストリッブ A スケール) である. ショットピーニング後の歯車の加工は行っていない. M2，S2 に対しては表面を電解研磨した場合（それぞ れ M2EP, S2EP と表す) についても曲げ疲労試験を行 った. 図 1 は, 試験歯車の硬さ分布を示す. 図 1 より, 高濃度浸炭歯車（M1～M3）の表面硬さは，共析浸炭 歯車（S1〜S3）の場合より 13\%程度增加することおよ びいずれの歯車においてもショットピーニングを施す ことにより，表面硬さがそれぞれ 4〜15\%程度増加す ることがわかる.

図 2 は, 試験歯車の表面近傍の断面 SEM 写真を示 す. 図 2 より，高濃度，共析浸炭いずれの場合も表面 から約 $15 \mu \mathrm{m}$ までの範囲に粒界酸化による異常層が認 められることおよび高濃度浸炭焼入れを施した場合 （M2，SH2）は，表面近傍に微細な炭化物が析出して いることがわかる.

2・1・2 街摹試験衝擊試験は, 重りを所定の高 さまで持ち上げ, 自然落下させ, 負荷伀達棒を介して 歯車の歯に衝撃荷重を作用させる歯車衝撃試験装置 ${ }^{(6)}$ を用いて行った。

2.1.3 曲げ疲労試験 曲げ疲労試験は, ディー ゼル機関用燃料噴射ポンプを利用した油圧式曲げ疲労 試験機(7)を用いて, 片振り応力条件下（最小応力： 零）で行った．荷重繰返し速度は毎分 700 回である.

\section{$2 \cdot 2$ 二円筒試硂}

$2 \cdot 2 \cdot 1$ 試験ローラ 試験ローラの形状・寸法を
図 3 に示す. 材料, 熱処理条件およびショットピー二 ング条件は，歯車の場合と同様で，表 2 に示すとおり である.ローラは，いずれも浸炭焼入れ後研削仕上げ を行っているが，ショットピーニング後は研削は行っ ていない，軸方向表面粗さ $R_{y}$ は，ローラ RS2P2， $\mathrm{RM} 2 \mathrm{P} 2$ が $2 \mu \mathrm{m}$ 程度, その他のローラでは $1.5 \mu \mathrm{m}$ 程度 である．また，ローラの硬さ分布は，歯車の場合とほ ぼ同様である。

2.2.2 面圧疲労試験面圧疲労試験は, 油圧式

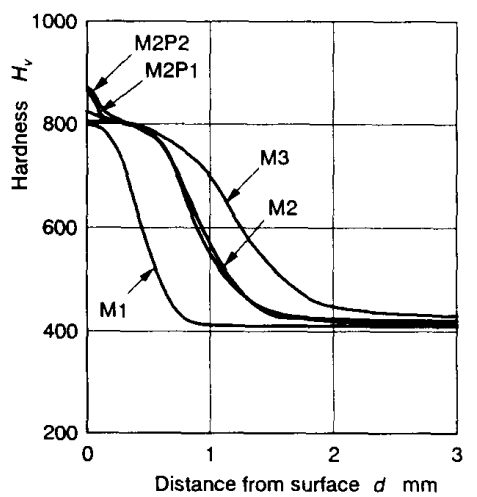

(a) $\mathrm{MACl} 4$

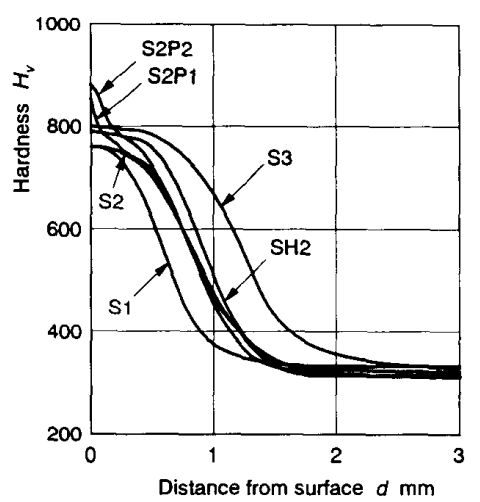

(b) SCM415

Fig.1 Hardness distributions of test gears

Table2 Heat treatment condition

\begin{tabular}{|c|c|c|c|c|c|}
\hline Gear (Roller) sign & Material & Heat treatment & $\begin{array}{c}\text { Carburizing } \\
\text { Time } \\
t_{c} \\
\end{array}$ & $\begin{array}{c}\text { Effective } \\
\text { case depth } \\
\text { d mm }\end{array}$ & $\begin{array}{c}\text { Surface } \\
\text { Hardness } \\
\text { Hv }\end{array}$ \\
\hline M1 (RM1) & \multirow{5}{*}{ MAC14 } & \multirow[t]{4}{*}{ Super-carburizing } & $2 \mathrm{~h} 50 \mathrm{~min}$ & $0.60(0.50)$ & $835(800)$ \\
\hline M2(RM2) & & & \multirow{3}{*}{$4 \mathrm{~h} 30 \mathrm{~min}$} & $1.10(1.04)$ & $840(810)$ \\
\hline M2P1 (RM2P1)* & & & & $1.23(1.03)$ & $875(860)$ \\
\hline $\mathrm{M} 2 \mathrm{P} 2(\mathrm{RM} 2 \mathrm{P} 2)^{* *}$ & & & & $1.13(0.98)$ & $890(870)$ \\
\hline M3 (RM3) & & & $7 \mathrm{~h} 40 \mathrm{~min}$ & $1.48(1.38)$ & $820(824)$ \\
\hline $\mathrm{SH} 2$ (RSH2) & \multirow{6}{*}{ SCM415 } & Time & $4 \mathrm{~h} 30 \mathrm{~min}$ & $1.05(0.93)$ & $730(700)$ \\
\hline S1 (RS1) & & \multirow{5}{*}{$\underbrace{\text { Earburking }}_{\text {Time }}$} & $2 \mathrm{~h} 40 \mathrm{~min}$ & $0.68(0.68)$ & $740(760)$ \\
\hline S2(RS2) & & & \multirow{3}{*}{$5 \mathrm{~h}$} & $0.99(0.85)$ & $745(760)$ \\
\hline $\mathrm{S} 2 \mathrm{P} 1(\mathrm{RS} 2 \mathrm{P} 1)^{*}$ & & & & $0.98(0.84)$ & $820(860)$ \\
\hline S2P2 (RS2P2)** & & & & $0.90(0.82)$ & $850(880)$ \\
\hline S3(RS3) & & & $8 \mathrm{~h}$ & $1.49(1.26)$ & $735(765)$ \\
\hline
\end{tabular}

( ): Roller, *: Shot-peened (arc hight $0.31 \mathrm{mmA}), \quad{ }^{* *}$ : Shot-peened (0.72 mmA) 
二円筒試験機(8)を用いて行った。回転速度，すべり率 は，低速（L）ローラでそれぞれ 1000rpm，-23.8\%， 高速（H）ローラで $1238 \mathrm{rpm},+19.2 \%$ ある．潤滑は 軸受油を用い, 油温 $313 \mathrm{~K}$, 油量 $0.4 \mathrm{~L} / \mathrm{min}$ で強制潤滑 した.

$2 \cdot 2 \cdot 3$ 摩耗試験摩耗試験は, 面圧疲労試験上 同じ試験機を用いて押付荷重 $P=15 \mathrm{kN}$ の下で行い, 適 当な繰返し数 $N$ において試験ローラの質量を測定し， 密度を用いて摩耗体積を求めた。

\section{3. 実験結果および考察}

$3 \cdot 1$ 衝撃および曲げ疲労強度に及ぼす硬化層厚さ と高漫度浸炭焼入れの影䭗図 4 は, 試験歯車に対 して衝撃試験を行ったときの衝撃破壊限度エネルギ 一昼と有効硬化層厚さとの関係を示す，衝撃破壊限度 エネルギーは，1回の衝撃荷重によって歯車が破壊し ない最大の衝撃エネルギーである. 図 4 より, 衝撃破 壊限度エネルギーは，いずれの有効硬化層厚さの場合 も，高濃度浸炭歯車のほうが共析浸炭歯車の場合より
も $15 \%$ 程度大きいことがわかる，このことから，高濃 度浸炭霜車は，共析浸炭雬車よりもじん性が大きいも のと考えられる. また, 衝撃破壊限度エネルギーは, いずれの歯車の場合も，有効硬化層厚さの増加につれ て直線的に減少する。これは，歯車のぜい性が硬化層 厚さの増加につれて増加することによると考えられる，

図 5 は, 硬化層厚さが異なる MAC14 高濃度浸炭歯 車（M1〜M3）および SCM415 共析浸炭歯車（S1〜 S3）に対する曲げ疲労試験結果を，図 6 は，曲げ疲労 限度荷重 $P_{u}$, 表面硬さ $H_{v}$ と有効硬化層厚さ $d$ の関係 を示す．図 5,6より，高濃度および共析浸炭歯車の 曲げ疲労限度は， $d$ が $1 \mathrm{~mm}$ 付近でともに最大值を示し， 曲げ疲労強度に対してはいずれの処理においても最適 硬化層厚さが存在することがわかる．また，高濃度浸 炭歯車と共析浸炭歯車の曲げ疲労限度はほぼ同じであ る．このように高濃度浸炭泋入れを施しても柬車の曲 げ疲労強度が増大しないのは, 次のような理由による と考えられる．高濃度浸炭焼入れによって歯車の表面 近傍に析出炭化物が形成され，この炭化物は残留才ー

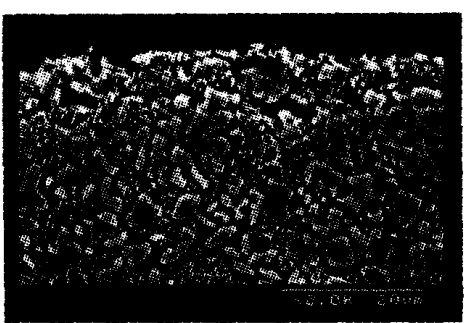

(a) M2

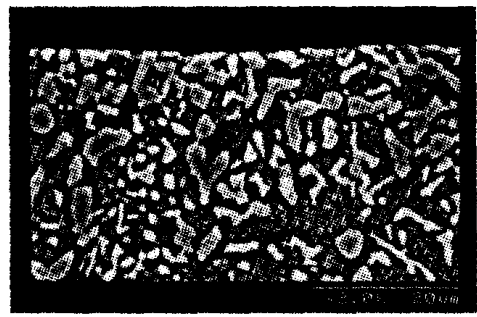

(d) M2EP

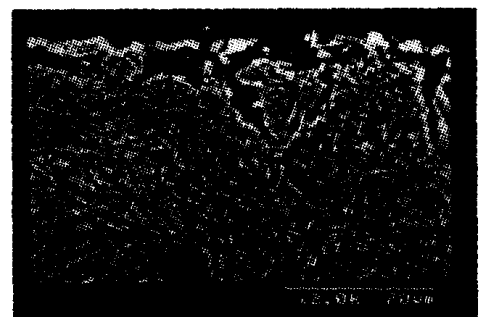

(b) S2

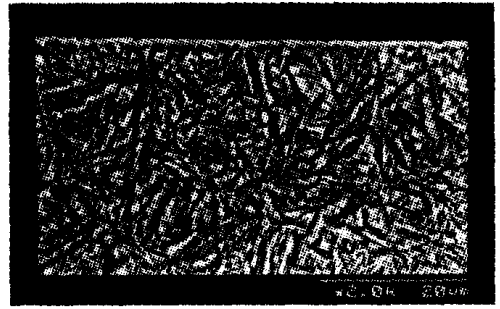

(e) S2EP

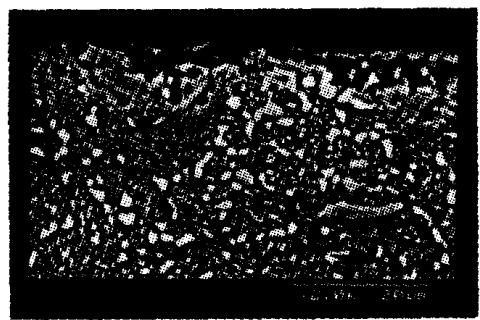

(c) $\mathrm{SH} 2$

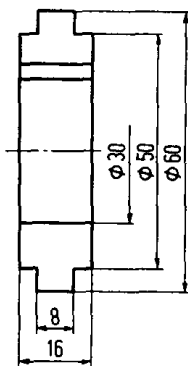

L roller

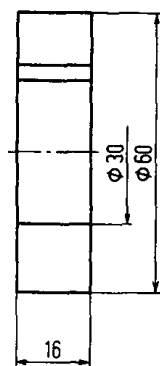

$H$ roller
Fig.3 Shapes and dimension of test rollers

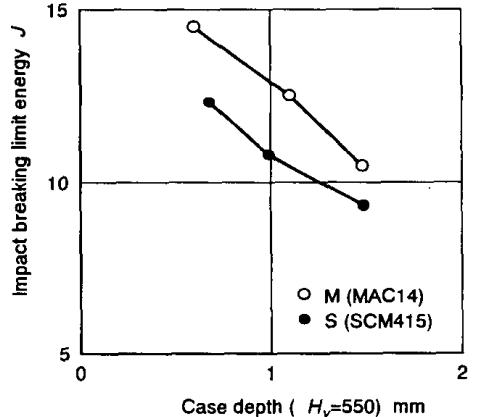

Fig.4 Relation between impact breaking limit energy and effective case depth 
ステナイトの機械的安定化に作用する ${ }^{(9)}$ ため、この析 出炭化物周辺の基地組織中に安定化した残留才ーステ ナイトが存在すると考えられる．この安定化した残留 オーステナイトがき裂の起点となるため, 高濃度浸炭 焼入れを施しても曲げ疲労強度が增大しないものと考 えられる ${ }^{(3)}$.

一般に浸炭焼入れ処理では表面に異常層を生じ，こ の異常層は機械的性質が劣るので曲げ疲労強度を低下 させると考えられ，共析浸炭㐘車においてはこの表面 異常層を除去することによって疲労強度を向上できる ことが知られている(10)(11).

図 7 は，歯元危険断面付近を電解研磨することによ つて表面異常層を削除した M2EP，S2EP（図 2参照） に対する曲け疲労試験結果を示す．図７より，高濃度 浸炭，共析浸炭歯車ともに異常層を削除した場合の曲 げ疲労限度が，異常層がある場合より $10 \%$ 程度增大し ていることがわかる：このことから，高濃度浸炭乘車

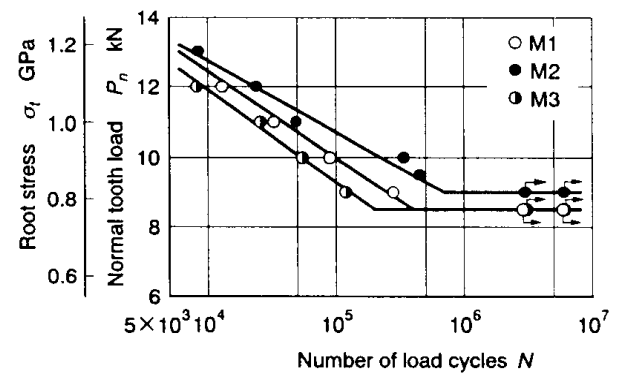

(a) $\mathrm{MAC14}$

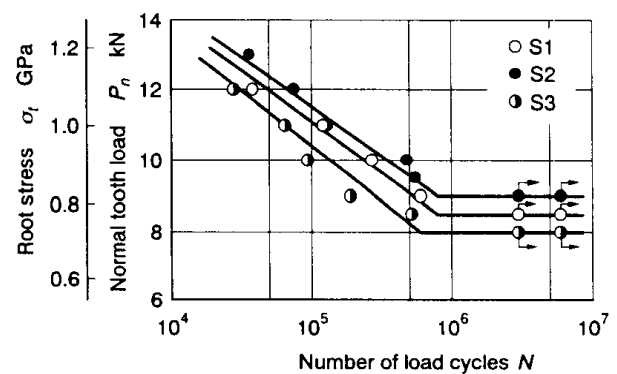

(b) $\mathrm{SCM} 415$

Fig.5 Bending fatigue test results

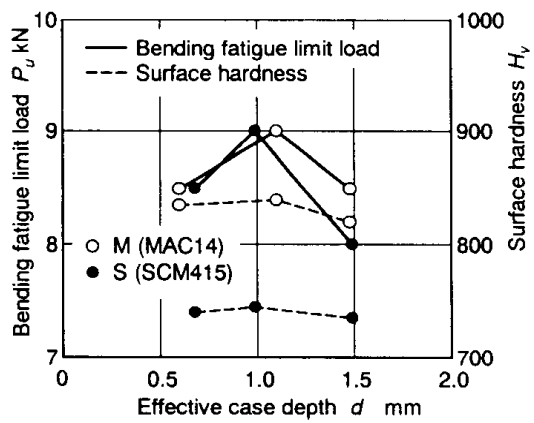

Fig.6 Effect of effective case depth on bending fatigue limit load
に対しても表面の異常層が疲労限度低下要因となるこ とがわかる.

図 8 は, 歯車 $\mathrm{S} 2, \mathrm{SH} 2, \mathrm{M} 2$ の $P_{n}$ と $N$ の関倸を示す. 図 8 より, SCM415 高濃度浸炭㐘車（SH2）の $P_{u}$ は, SCM415 共析浸炭歯車（S2），MAC14 高濃度浸炭歯車

（M2）の場合より $10 \%$ 程度小さくなっている。これ より，一般の浸炭用鋼に高濃度浸炭焼入れを施しても 曲げ疲労強度に対しては，効果がないもの之考えられ る. 高濃度浸炭焼入れを施した場合の疲労強度は, 炭 化物間距離の影響を受け，炭化物間距離の增加につれ

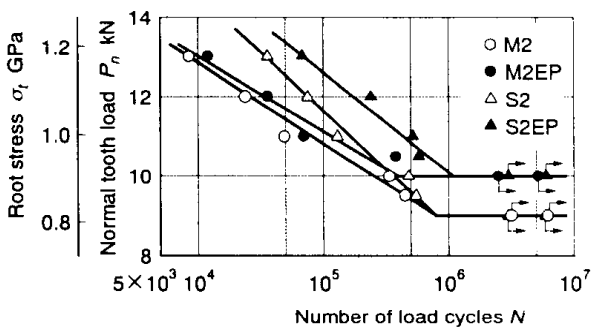

Fig.7 Bending fatigue test results (M2, M2EP, S2, S2EP)

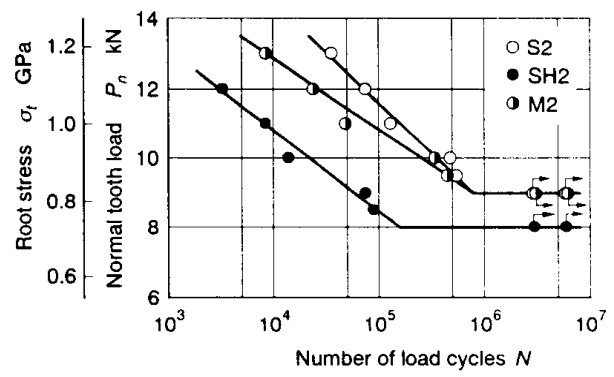

Fig.8 Bending fatigue test results (M2, S2, SH2)

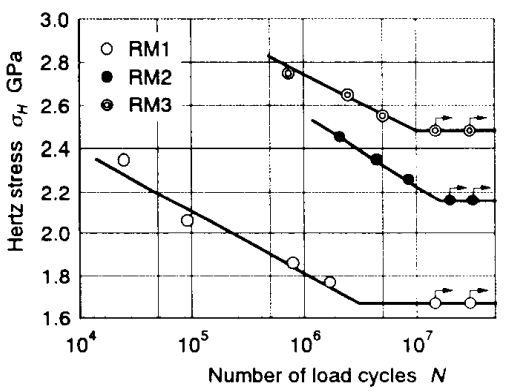

(a) $\mathrm{MAC14}$

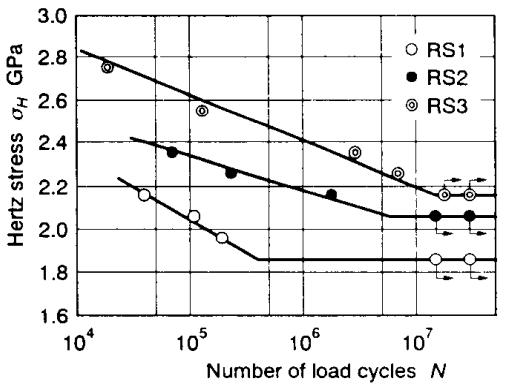

(b) SCM415

Fig.9 Contact fatigue test results 
て低下すると考えられており ${ }^{(3)}, \mathrm{SH} 2$ の表面近傍にお ける炭化物の析出状態は $\mathrm{M} 2$ よりも粗であるため（図 2 参照），SH2 の曲げ疲労強度が低下したもの之考元 られる。

$3 \cdot 2$ 面圧疲労強度に及ぼす硬化属厚さと高漕度漫 炭の影響図 9 は, 硬化層厚さの異なる MAC14高 濃度浸炭ローラ（RM1〜RM3）および SCM415 共析浸 炭ローラ（RS1〜RS3）に対するヘルツ応力 $\sigma_{H}$ 之繰返 し数 $N$ の関係を, 図 10 は, 面圧疲労限度 $\sigma_{H u}$ 之有効硬 化層厚さ $d$ の関係を示す. 損偒は, いずれのローラも 幅の狭い Lローラのほうに生じ, スポーリングが支配 的であった．図 9,10より, 高濃度浸炭および共析浸 炭ローラのいずれにおいても， $\sigma_{H u}$ は $d$ の增加につれ て增大する傾向を示すが，その程度は RS よりも RM のほうが大きく, $d \leqq 1 \mathrm{~mm}$ の場合には, RS と RM の差 は小さいが， $d=1.5 \mathrm{~mm}$ 程度になると RMのほうが $15 \%$ 程度高くなる.これは, RM の表面にある微細な炭化

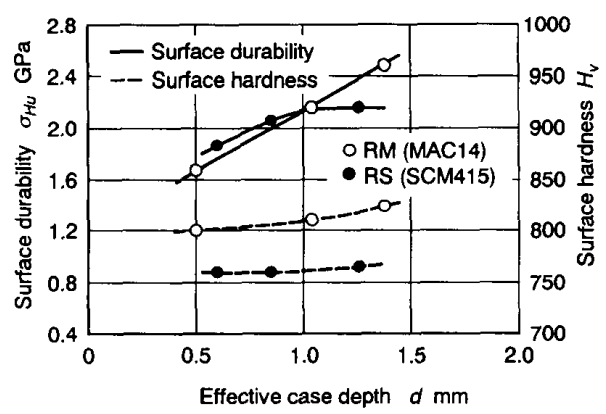

Fig.10 Effect of effective case depth on surface durability

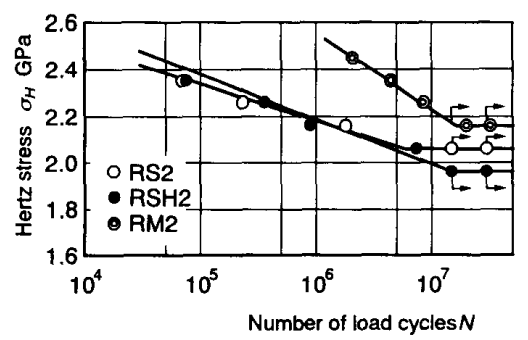

Fig.11 Contact fatigue test results (RM2, RS2, RSH2)

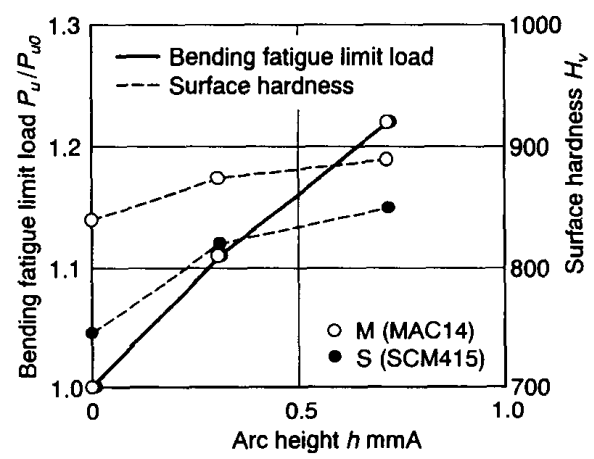

Fig.12 Effect of arc height on bending fatigue limit load
物が， $d$ の增加につれて増大することによると考えら れる.これらのことから, 曲げ疲労強度に対しては高 濃度浸炭の効果は認められなかったが, 面圧疲労強度 に対しては硬化層厚さが大きい場合には, かなりの効 果が期待できるものと考えられる.

図 11 は，ローラ RS2, RSH2, RM2 の $\sigma_{H}$ と $N$ の関 倸を示す. SCM415 高濃度浸炭ローラ RSH2 $\sigma_{\sigma_{H u}}$ は, 曲げ疲労限度の場合之同様に, MAC14 高濃度浸炭口 一ラ RM2, SCM415 共析浸炭ローラ RS2 の場合よりも 小さい。これらのことより, 面圧疲労強度の場合にお いても, 曲げ疲労強度の場合之同様に, 一般の浸炭用 鋼に高濃度浸炭焼入れを施しても効果があまり期待で きないものと考えられる. したがって, 面圧疲労強度 においても高濃度浸炭焼入れの効果を十分に得るため には，一般の浸炭用鋼ではなく，高濃度浸炭用鋼を用 い，さらに適切な硬化層厚さ $(d \geqq 1.5 \mathrm{~mm})$ を選択する 必要がある。

$3 \cdot 3$ 曲げ・面圧疲労強度に及ぼすショットピーニ ングの影響 図 12,13 は, ショットピーニングを 施した歯車およびローラに対するアークハイト $h$ と曲 げ疲労限度荷重 $P_{u}$, 面圧疲労限度 $\sigma_{H u}$, 表面硬さ $H_{v}$ の 関係を, 縦軸に $P_{u} / P_{u 0}, \sigma_{H u} / \sigma_{H u O}\left(P_{u O}, \sigma_{H u O}\right.$ : ショッ トピーニングを施さない場合の曲げ, 面圧疲労限度) と $H_{v}$ をとって示す. 図 12 より, 高濃度, 共析浸炭歯 車のいずれの場合も， $P_{u}$ は $h$ の増加につれて增大する 傾向を示し，適切なショットピーニングを施すことに

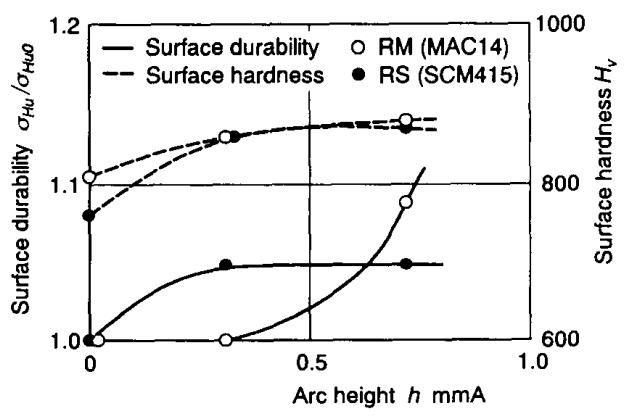

Fig.13 Effect of arc height on surface durability

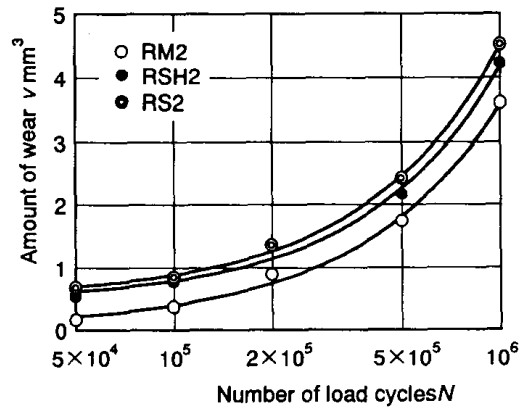

Fig14 Relation between amount of wear and number of load cycles 
より， $P_{u}$ を $20 \%$ 程度増大させることが可能であること がわかる. また, 図 13 より, 高濃度, 共析浸炭ロ一 ラのいずれにおいても， $\sigma_{H u}$ は $h$ の増加につれて增大 する傾向を示し，ショットピーニングにより $\sigma_{H u}$ を $10 \%$ 程度增大させることが可能であることがわかる.

\section{4 糜耗試験結果 図 14 は, 試験ローラ RM2,}

RSH2, RS2 における摩耗量 $v\left(\mathrm{~mm}^{3}\right)$ と繰返し数 $N$ の 関係を示したものである. 図 14 より, 摩耗量は RM2 が最も小さく， RSH2， RS2 の順に大きくなることが わかる.このことから, 高濃度浸炭ローラの耐摩耗性 は共析浸炭ローラよりも高いことおよび一般浸炭用鋼 材に高濃度浸炭を施しても, 曲げおよび面圧疲労強度 には効果が期待できないが，摩耗に対しては多少効果 があることがわかる.

\section{4. 結言}

本研究で明らかになった諸点を要約すると次のよう になる。

（1）衝撃破壊限度エネルギーは，いずれの有効硬化 層厚さの場合も, 高濃度浸炭歯車のほうが共析浸炭歯 車の場合よりも $15 \%$ 程度大きい.

（2）MAC14高濃度浸炭歯車の曲げ疲労強度は, SCM415 共析浸炭歯車の場合とほぼ同じになり, 曲げ 疲労強度に対する高濃度浸炭焼入れの効果は小さい.

（3）高濃度および共析浸炭歯車のいずれにおいても, 曲げ疲労強度に対しては最適硬化層厚さ（1mm 程度） が存在するが, 面圧疲労強度については存在せず, 硬 化層厚さの增加につれて単調に増大する.

（4）MAC14 高濃度浸炭ローラの面圧疲労限度は, 有 効硬化層厚さが小さい場合には, SCM415 共析浸炭口 一ラの場合とあまり変わらないが, 有効硬化層厚さが 大きい場合には高濃度浸炭ローラのほうが高くなる.

（5）曲げ疲労, 面圧疲労強度のいずれに対しても, 高濃度浸炭焼入れの効果を得るためには高濃度浸炭用 鋼材を用いる必要がある.

（6）高濃度および共析浸炭歯車の曲げ疲労および面 圧疲労限度は, 適切なショットピーニング条件を選ぶ ことによりそれぞれ 20，5～10\%程度增大する.
（7）高濃度浸炭ローラの耐摩耗性は，共析浸炭の場 合よりも高い。

最後に，本研究を行うに当たり実験および資料整理 に熱心に協力された鳥取大学文部科学技官・難波千秋 氏，試料作製にご協力いただいた元 同和鉣業(株)・岩野 利彦氏ならびに三菱製鋼梾・岡部 功氏に対し厚くお 礼申し上げる。

\section{文献}

(1) 内藤武志·木林靖忠·中村浩三，高濃度浸炭の技術，熱処 理, 26-2, (1986), 157-162.

（2）秋葉義明·原田昭治·岩野利彦·山田修司·松岡秀樹, 疲労 強度に及ぼす浸炭条件の影響，機論，59-564，C(1993)， 1827-1833.

（3）瓜生英樹·黒島義人·原田昭治，高濃度浸炭鋼の疲労特性 に及ぼす析出炭化物の影瑤, 機論, 61-590, A(1995), 2109-2114.

(4) 永村和照·池条清隆·志賀 隆·岩野利彦, 高濃度浸炭鋼歯 車の曲げ強度, 機構論, No.965-1(1996), 231-232.

(5) 三菱製鋼(株), 三菱製鎆の特殊用途鋼 MAC14 カタログ.

（6）坪倉公治・小田 哲·小出隆夫，低温化における浸炭焼入れ 㐘車の曲げ疲労強度に及ほすす衝撃荷重の影響, 機論, 63609, C(1997), 1783-1787.

(7) 会田俊夫·小田 哲·中島利勝, 歯車の曲げ疲れ強さに関す る研究(第 1 報, 疲れ過程における歯元すみ肉部の組織と 残留応力変化), 機論, 32-233, (1966), 137-142.

(8) 小田 哲·小出隆夫·安藤順一, 調質鋼口-ラの面圧強度に 及ぼす荷重変動の影響，機論，50-457，C(1984)，16391646.

(9) H. J. Neuhauser and W. Pitsch, Acta. Met, 19(1971), 337.

(10) 柳晟基·井上克巳·加藤正名·大西昌澄·下田健二, 浸炭菌 車の曲げ疲労強度に及ぼす表面処理の影響，機論，60572, C (1994), 1391-1396.

(11) 小田 哲·小出隆夫·松井光次·山本 謙, 浸炭焼入れ歯車の 曲げ疲労強度に及ぼす粒界酸化の影響, 機論, 54-501, C (1988), 1135-1139. 